\title{
RESERVATION SYSTEM WITH THE PAN AMERICAN ROUND AND CASES RESERVATIONS ON 1951 GENOCIDE CONVENTION
}

\author{
Yaya Kareng \\ Sripatum University (SPU) Thailand \\ yahya31490@gmail.com \\ Hartanto \\ Poltektrans SDP Palembang \\ hartantosatya@gmail.com \\ Choirul anam \\ Sultan Agung Islamic University \\ independentanam@gmail.com
}

\begin{abstract}
A reservation is a unilateral statement made by a State at the time of signing, accept, ratify, ratify or accede to the treaty, which is the main content is to issue or to modify the legal effect of certain provisions in its enforcement against the State (KW 1969). Initially reservation (requirements) are defined differently based subjects that provide definition. As for the definition independent of the reservation that in general it is a unilateral statement put forward by a country at the time expressed consent to be bound by a treaty, which said "Refuse to accept or recognize or do not want to be tied to, or unwilling to accept the legal consequences of one or more provisions of the agreement, or to modify or customize the content or provide its own meaning on one or more provisions of the agreement in accordance with the needs of the country ", dissent is possible if there is no commonly agreed definition.
\end{abstract}

Keywords: Agreement; International; Reservations.

\section{A. INTRODUCTION}

According to Act No. 24 Of 2000 Article 1 (d), Reservation is a unilateral statement of a State to exclude the application of certain provisions of a treaty in the formulation made when signing, accepting, approving or ratifying multilateral agreements ${ }^{1}$.

But with the birth of the Wina Convention in 1969 as an instrument of international treaty law, the definition of the terms have are acceptable in general based on the definition contained in article 2, paragraph 1, point d "requirement means a unilateral statement, the form and name it whatever made by a State, when signing, ratified, exception, approving or

1 Amos, Abraham. 2005. Indonesian Nationality Constitutional System. PT. Raja Grafindo Persada: Jakarta. 
acceding to a treaty, which is meant to exclude or modify the legal effect of certain provisions of the treaty in its application to the relevant country ". Thus the substance of Article 2 (1), d Wina Convention among others is a unilateral statement, regarding the timing of the filing requirements, and with regard to the substance, purpose, and the purpose of the requirement itself, as well as the filing requirements that must be in written form².

\section{B. DISCUSSION}

\section{Effect of State Sovereignty in Pressing To Birth An Instrument Of Terms and Conditions (Reservations)}

Resevation as described above is based on article 2, paragraph 1 section d Wina Convention 1969 on the agreement. Agreement is a manifestation of the desire of the countries on an international rules whose application is not contrary to the constitution and certainly not to harm the sovereignty of each country. Sovereignty is one of the elements forming the country so that the rules of international law sought as relevant as possible to the common law rule in every country in the world. Sovereignty according to international law and Indonesian dictionary by Drs. Prajogo Susilo, SH, published Intellectual Discourse means "highest authority for the administration of the state, region; the sovereignty of a country ", with reference to the definition above, a problem will arise when countries participating in an international convention, in which each country must have a constitution difference ${ }^{3}$.

The realization that the system and the structure of the international community, the countries as the main subject of international law has sovereignty, and on the basis of the sovereignty of the country can not be forced to accept or agree something that is not in accordance with their interests. In conjunction with an international treaty, on the basis of the sovereignty of the country have every right to decide whether to agree or reject bound by an international treaty. Problematic is when in agreement that there are some provisions that harm and there is also a benefit for the country, the choice is agree to be bound or not at all.

Whichever option taken will cause further problems for both the country and for the treaty itself, even in a broader scope will have an impact to international community in general, much less if the agreement was a global multilateral international agreement. The problem that arises for the country is if not bound by the agreement even though the majority of the provisions of the agreement profitable for him,

2 Azhary, Muhammad Tahir. 2004. Ilmu Negara. Prenada Media: Jakarta.and Sumaryo. 2008. Law of Treaties. Jakarta.

3 Budiardjo, Miriam. 2008. Fundamentals of Political Science. PT. Gramedia Pustaka Utama: Jakarta. 
otherwise if imposing bound to the agreement when there are several provisions detrimental to the country, this puts the country in a difficult choice ${ }^{4}$.

Further to the agreement itself, it will hinder the development of international law in which the sources of international law are international agreements where fewer countries who agree to be bound by the agreement. It will also hamper the ideal concept of the treaty in order that the real implementation.

For the international community in general, inhibition of an international treaty developed into a significant positive legal norms will hinder the birth of a means to regulate the life of the international community. With the above two options will certainly be difficult to be met by the countries that participate in the agreement to be bound because it is too extreme.

To accommodate the interests of each country without prejudice to the sovereignty of one side opposite to the provisions in the agreement, then introduced the international legal order called reserve (requirement) for sovereignty of the countries in the attachment to an international agreement with the treaty itself. This makes it clear that the requirement (reservation) was born out of a gap between sovereignty and the provisions of the treaty.

Regarding the requirements of the instrument plus stipulated in the Vienna Convention of 1969 on article 2, paragraph $1 \mathrm{~d}$ "definition of the terms", and regulated in five articles, namely article 19, "the rules concerning the filing of a requirement to restrictions on international treaties", chapter 20 "regarding acceptance or rejection the proposed requirements of a country by the other participating countries ", article 21" regulates the legal consequences of the terms "article 22 " is set on the recall of requirements or a refusal ", article $23 "$ in this article shall be the procedures terms thoroughly ". With the existence of clear rules regarding the requirements will make it easier for countries participating in the Convention or a third country if you want to participate bound by treaty to exclude some provisions that permitted by the treaty itself ${ }^{5}$.

In general, international agreements therein followed by the state as a participant-oriented (or a legal instrument) the provisions of the Wina Convention 1969 on the agreement. The provisions in the convention specifically Wina there are eight (8) sections consisting of 85 chapters, which are expected to accommodate the provisions of international law for an agreement.

4 Parthiana, I Wayan. 2002. International Contract Law Part 1, Bandung.

5 Prajogo, Susilo. 2007. Dictionary of International Law and Indonesia, First Edition 


\section{Differences Reservation System with the Pan American Round And cases reservations on 1951 Genocide Convention (prevention and condemnation of the genocide crime)}

In the early days of the birth of the requirements until the of 2008 there are two kinds of system requirements. Two systems that requirement was unanimously system requirements and system requirements of pan-American. System requirements unanimously a mechanism filing requirements by a country wishing to be bound to a treaty that is based on the approval of all member countries of the agreement, in other words, if there are members who oppose the terms proposed by the state that wants to bind himself to the agreement will not be accepted as a member. In this system, all member states must agree to the terms proposed by countries that want to become members so that the requirements have binding force and apply positive, that does not mean that countries that want to become members had had to accept the overall provisions in the agreement or not a member.

The unanimous voice systems, such as mashab contract in civil law which prefers the integrity of the substance of the contract so as not to injure the intent and purpose of the treaty. A significant improvement over the system's unanimous occurred in the period before World War I and II, which at that time the League of Nations the most widely used this mechanism, and the unanimous vote system is regulated in Article 20 paragraph 2 of the Wina Convention $1969^{6}$.

Furthermore, the second system is pan-American system, the system is called pan-American system because the system was introduced and applied first American continent, the regional organization in 1932 with the name of the Organization of American States. The mechanism of the system is not too complicated according to the authors for their application and enabling a rapid expansion of international treaty law itself.

In summary the system of pan with a state intending to be bound to the agreement a requirement in terms of the agreement and these requirements receive a response pros and cons of member states and so the agreement remains valid in general and the requirements apply only to state of the pro proposed requirements and the cons does not apply to the agreement and the legal consequences for the country that put forward the requirements and the cons on the requirements of the agreement does not apply to him. Regarding the pan-American system is arranged in Wina Convention in 1969 in chapter 20 verses 4, 5, Article 21 paragraph 1, 2, 3, and article 22, paragraph 1, 2, 3, and Article 23 paragraph 1, 2, and 3.

6 Adolf, Haula. 2004. The International Trade Law. 
From the description above it is clear both systems requirements difference, that of language terminology may illustrate the fundamental difference. Here also appears very clearly from the provisions that govern where the reservation pan Americans are getting a convention in the settings of the system in 1969 Wina unanimously, it is not out of the system dynamics participation pan american more than unanimously system.

To better understand the reservations (a requirement) with its place as the international legal order authors present a case that explores the theoretical level to the implementation of the requirement itself, as follows ${ }^{7}$ :

Reservation to the Convention on Genocide, 1951.

a. Parties Involved:

1) UN As an international organization that organizes Genocide Convention 1951 "Convention Concerning Crime And Punishment of Genocide".

2) UN member states, which in 1948 unanimously agreed on the Convention on Genocide by the number of UN member states is 56 countries, and third countries wishing to participate bound for conventions that are universal and conventions provide that possibility.

3) International Court of Justice Advisory Opinion Giver represented twelve (12) international court judges.

b. Case

1) On 9 December 1948, the UN General Assembly passed a convention that Convention on the Prevention and Punishment of the Crime of Genocide (Convention on prevention and punishment of crimes genocide) by Resolution No. 206 / III / 48, and the force on January 12, 1951, the problem turned out to be in the convention does not set on the Reservation (requirements), so it is not clear whether the state would have tied the Genocide Convention alllowed to a requirement or not at all.

2) Inside the convention process to bind the countries, it turns out there are some countries that apply for the current requirements of express consent to be bound in the 1951 Genocide Convention.

c. Problem solving:

1) Because in the Genocide Convention which there are no rules governing the Reserve splisit. Though it is a question of international law, which is very large considering this convention are accommodated by the international organization, the UN General Assembly at the time it was issued Reselusi

7 "Convension of Vienna 1969 International Agreement on" Copy Script Translated to Indonesian.

Suryokusumo 
number 478 / V / 1950, which begs Advisory Opinion (legal opinion) to the International Court of Justice, by pointing to the problems that faced by the 1951 Genocide Convention, as follows;

2) As far as the Convention on Genocide, in the case of a country which consented to be bound by the convention:

3) Can the state filing requirements is seen as a party or participant at the convention while maintaining the requirements put forward that, if the requirement was rejected by one or more of the participating countries, but not denied or approved by the other participating countries.

4) If the answer to question $A$ is positive (affirmative), what is the legal effect of these requirements in the relationship between the state filing requirements and:

a) State Parties who rejected that requirement?

b) The participating countries which accept or approve it?

5) Is the legal consequences with regard to the answers to questions $a$, if an objection or rejection of the requirements put forward by:

a) Countries that signed the convention but not yet declared agreement to be bound or not ratified?

b) State entitled to sign it or acceding to it but it did not or have not done?

6) In answering this question, the court stated;

a) All of these questions is expressly limited by General Assembly resolution PPB which only relates to the Convention on the genoside, therefore, the answer will be given by the Court also expressly restricted to the convention only. Court will find the answer in the norms or rules of law concerning the legal consequences reservation and acceptance and rejection of the reservation in multilateral agreements ".

Furthermore, the court has said that an international agreement is not binding for countries that do not agree to be bound and vice versa. Court notice express an opinion in the case of internal and external factors of this Genocide Convention. Factors internal among others, include a consent mechanism treaty system uses unanimously aggravated, that is unanimously exacerbated was at the time the deal was taken held a vote which is more likely to agree (majority) and the mechanism unanimously for the agreement Genocide is, in other words already exist party (country) contiguous (the minority at the time of voting) unanimously this, and also the intent and purpose of the Genocide Convention is a convention that parmanent and universal. Parmanent and universal widely interpreted that the convention is a manifestation of pure acceptance 
of the purpose of humanity and human civilization. So the convention is an absolute convergence of interests by adhering to the principles of morality, regardless of profits and losses or only on the balance of rights and contractual obligations just as intended and purpose of the treaty.

External factor is the need to note the conditions for the application of the convention Genocide which going to nature more flexible for the integrity of the convention, plus the United Nations as a party to accommodate the implementation of the convention is very universal and rules of the countries that could be a participant under the provisions of the Convention (Article XI of the Convention ). A further factor is understood that thick at the time, where this understanding re-center that the intent and purpose of the treaty could not be thwarted by a unilateral decision or a special agreement between several parties to the treaty, this understanding is based on the principle of the sovereignty of each country (this understanding to develop and a cornerstone of making the contract "is a contract must be intact and round").

That's two factors that affect the convention Genocide, then the court argued that the intent and purpose of the convention is to limit, either restrict the freedom to apply the requirements or rejection of the terms such as the purpose and objectives of the United Nations and countries agreed of agreement so that more and more countries participating in the agreement. So filing requirements or rejection of the requirements to be considered an act of consummation of the agreement as long as it is relevant to the intent and purpose of the treaty.

Regarding the report with regard to this issue, which are acceptable by the board of the League on July 17, 1927, which states that often occur in secret agreement which has its own role on the reservation in an agreement, but this does not confirm the existence of regulations. Then look at the habits of the rejection of the requirements are very often not the case in the agreement that consequently there is no reason to create a rule this is kind of international law. The most well Presfictive adopted is that the recommendations made to the Board of LBB on that date was the starting point of an administrative practice which is applied and adhered to among secretariat LBB.

Finally, the ICJ by a vote of seven judges approved, while five judges refused, giving the Advisory opinion on a petition filed by the United Nations, and expressed ${ }^{8}$;

a. That if there is a country that is a requirement that was rejected by one or more countries participating in the convention but is approved or rejected by countries other participants, states that a requirement that can be considered a participant in

8 Ibid. 
conventions, when requirements that correspond to or contradict with the intent and purpose of the convention, but on the contrary if the requirement is contrary to the intent and purpose of the convention, the country can not be considered participants in the convention.

b. That if one of the participants rejected the terms proposed by a country which he considers contrary to the intent and purpose of the convention, the country was in fact can assume that the state filing requirements are not as a party or participant at the convention.

\section{CONCLUSION}

Reservation is a unilateral statement of a State to exclude the application of certain provisions of a treaty in the formulation made when signing, accepting, approving or ratifying multilateral agreements.

If a country that is a requirement that was rejected by one or more countries participating in the convention but is approved or rejected by countries other participants, states that a requirement that can be considered a participant in conventions, when those requirements in accordance with or contrary to the intent and the purpose of the convention, but on the contrary if the requirement is contrary to the intent and purpose of the convention, the country can not be considered participants in the convention.

hat if one of the participants rejected the terms proposed by a country which he considers contrary to the intent and purpose of the convention, the country was in fact can assume that the state filing requirements are not as a party or participant at the convention. 


\section{BIBLIOGRAPHY}

Amos, Abraham. 2005. Indonesian Nationality Constitutional System. PT. Raja Grafindo Persada: Jakarta.

Azhary, Muhammad Tahir. 2004. Ilmu Negara. Prenada Media: Jakarta.

Budiardjo, Miriam. 2008. Fundamentals of Political Science. PT. Gramedia Pustaka Utama: Jakarta.

Parthiana, I Wayan. 2002. International Contract Law Part 1, Bandung.

Prajogo, Susilo. 2007. Dictionary of International Law and Indonesia, First Edition Adolf, Haula. 2004. The International Trade Law.

"Convension of Vienna 1969 International Agreement on" Copy Script Translated to Indonesian. Suryokusumo and Sumaryo. 2008. Law of Treaties. Jakarta. 